\title{
Political and stakeholders' ties in European Union Agencies
}

\section{Ixchel Pérez-Durán}

\begin{abstract}
Some scholars consider that European Union agencies (EAs) were created as independent bodies in order to enhance the credibility of the European Union decision-making process. Scholars have typically focused on analyzing the relationship that these agencies have with politicians. However, relatively little attention has been paid to their relationship with stakeholders. This study examines the professional trajectory of EA board members, identifying their career ties with politicians and stakeholders. Using an original dataset on the career trajectories of 338 top-officials in $33 \mathrm{EAs}$, the findings provide evidence that the type of appointing body matters: On the one hand, the European Parliament is more likely - than the Commission - to appoint individuals having career ties to politicians; on the other hand, multiple veto players are less likely to designate board members linked to political players. Additionally, the findings suggest that agencies performing regulatory tasks seem to be more incline to have lower levels of de facto independence from politicians.
\end{abstract}

\section{Correspondence Address:}

Ixchel Pérez Durán, Institut Barcelona d'Estudis Internacionals (IBEI), Ramon Trias Fargas, 25, 08005 Barcelona, Spain. Email: iperez@,ibei.org.

\section{Introduction}

The international diffusion of the agencification process has resulted in the creation of different types of independent and specialized institutions that are not subject to majoritarian democratic procedures (Follesdal and Hix 2006). This process of "depoliticization" has led to the creation of non-elected institutions, such as central banks or regulatory agencies, which carry out executive powers over a broad range of policy issues (Flinders and Buller 2006; Wood 2015). Given the expansion of the "regulatory capitalism" (Levi-Faur and Jordana 
2005) some scholars have emphasized that the "rise of the unelected" has evolved into a "new separation of powers" (Vibert 2007). Although there is no consensus on characterizing such processes as a "separation of powers", the number of regulatory agencies has markedly increased around the world (Jordana et al. 2011; Fernández-i-Marín et al. 2016). At the European Union level, there are 33 decentralized European Union agencies (EAs) that participate in the policy process of a wide range of issues. ${ }^{1}$

Although the current literature distinguishes between EA autonomy from two types of actors —independence from politicians and independence from the regulatees (Jordana et al. 2011) - most scholars have focused on the analysis of their institutional independence from the political sphere, that is, independence from their political principals (e.g., Ennser-Jedenastik 2015, 2016; Fernández-i-Marín et al. 2016; Gilardi 2002; Hanretty and Koop 2012; Hanretty and Koop 2013; Wonka and Rittberger 2010). What is missing in the literature is an analysis of the relationship that EAs have not only with politicians, but also with interest groups. Given that EAs were created to respond to the "credible commitment" problem —understood as the delegation of competencies to independent agencies as a solution to deal with the incentives of politicians to carry out time inconsistent policies- (Gilardi 2002; Majone 1996), it has been, and continues to be important to analyze whether the decision-making of such bodies is related to the interests of certain external organizations or groups.

This study aims to examine the professional backgrounds of EA board members with the aim of identifying their career ties to politicians and stakeholders. The study does not assume that

\footnotetext{
${ }^{1}$ According to Kelemen (2012: 393), an agency can be defined as "an organ of the EU created by an act of secondary legislation with a distinct legal personality and a certain degree of organizational and financial autonomy."
} 
actors are only driven by their professional backgrounds, nor that policy decisions within agencies are only driven by the sum of their members' individual preferences and actions. Nevertheless, studies based on career trajectories have demonstrated that the career path or background of a person shapes their beliefs and, thus, their policy preferences and decisions (Adolph 2013; Hooghe 1999; Schneider 1993). This article is based on previous studies conducted by Ennser-Jedenastik $(2015,2016)$ and Fernández-i-Marín et al. (2015), who have examined the career trajectories of agency board members with the aim of assessing political independence in national regulatory agencies.

The article also aims to examine whether appointment rules lead to the election of board members with certain links to stakeholders and politicians. Particularly, in line with Fernández-i-Marín et al. (2015), this study seeks to examine the type of appointing body in order to identify whether the European Parliament (EP), the Council, the Commission, the Member States, or multiple veto players are more likely to appoint individuals with career ties to politicians and stakeholders. The article also investigates the effect of other potential explanatory factors, such as agency formal independence, and the role of agencies performing regulatory and informative tasks.

The assessment of political and stakeholder ties is based on an original dataset of the career trajectories of current and former EA board members who served during the period between January 2010 and September 2016. In particular, I focused on examining board members appointed by the Council, the EP, and the Commission. I also included a simple random sample of representatives of Member States. The construction of this dataset is based on the method followed by Ennser-Jedenastik (2015) and Fernández-i-Marín et al. (2016) to examine pro- 
fessional trajectories in national regulatory agencies. This study covers 338 management board members in the 33 existing EAs.

The results show that 15.4 percent of the board members (52 board members) have career political ties - these are particularly present in some agencies, such as ACER, ECHA, EMA EMCDDA and ETF-; and 39.1 percent (132 members) have career stakeholder ties - this practice is more common in ACER, EBA, EFSA, EIOPA, ESMA, GSA, SRB and EEA-. Among board members having ties to stakeholders, 62.3 percent have ties to business groups/ private consultancies, 6.2 percent to NGOs, 3.9 percent to trade unions, and 19.2 percent to international organizations. In addition, the results provide evidence that the EP is more likely - than the Commission - to appoint individuals having political ties as management board members. The findings also demonstrate that multiple veto players are less likely to designate board members linked to politicians. Moreover, the study shows that agency characteristics matter, in particular, that agencies performing regulatory tasks seem to be more inclined to have lower levels of de facto independence from politicians. Finally, an analysis including sampling weights — carried out with the aim to balance the under-representation of Member States representatives included in the analysis - suggests that both the Council and multiple veto players are more likely to designate board members having ties to stakeholders, and that regulatory agencies are also more likely to have board members with stakeholder ties among their members. However, given that the sampling error is large, due to the small sample size of Member State appointees included in the analysis, the factors that affect the presence of stakeholder ties cannot be confirmed. 
This article contributes to the literature by examining the professional trajectories of policymakers serving in non-majoritarian and specialized institutions at the European Union level. In particular, I limit my attention to high-ranking appointees of EAs. Before taking for granted that these agencies are able to enhance the credibility of the policy-making process, it is important to know who their top officials are, and who could be promoted, in terms of professional experience, to a high-ranking position within an agency. Therefore, this article is the first attempt to provide a map of the professional background of EA board members. By doing so, this article also contributes to the literature by identifying whether there is a "bias" in the type of skills and professional experience that these appointees have.

The article is structured as follows. Section 2 discusses the literature on agency independence and makes the case for the utility of career analysis as a means of identifying interpersonal ties. Subsequently, Sections 3 and 4 address the expected hypotheses with respect to political and stakeholder ties within EAs. The operationalization and the research design are discussed in Section 5, which is followed by the empirical analysis and the discussion of the results (Section 6).

\section{Theoretical framework}

Agency independence as (a source of) legitimacy: Independence from politicians and regu-

\section{lated interests}

As noted above, the agency model is based on the notion that agencies must be independent (Majone 1997), which implies the capacity of agencies to decide over their internal activities and the use of their resources without interference (e.g. Gilardi 2002). In general, the current 
literature suggests to conceive independence not only from politicians but also with respect to the regulatees, that is to say, from "representatives of the sectors targeted by regulation" (Gilardi and Maggetti 2011: 204).

Given the temporal limitations (the "pro tempore" nature) of democratic governments, independence from politicians has been presented as a solution to avoid the "short-term" nature or "time inconsistency" of policy-decisions carried out by democratically elected politicians (Majone 1996). However, contrary to the argument on independence from politicians, there are two different positions regarding the relationship that agencies may have with stakeholders: on the one hand, some scholars suggest that independent agencies should be close to the actors involved and/or affected by policy decisions as a vehicle for generating credibility. The argument is that the inclusion of stakeholders favors the "consensus and the exchange of knowledge" in policy-making at the post-delegation stage of EAs (Borrás et al. 2007). On the other hand, other authors suggest that such non-elected bodies should be independent from regulatees in order to avoid regulatory capture, that is, in order to avoid that private interests used such agencies for their own ends (Stigler 1971).

Studies on organizational theory have emphasized that, in order to understand the behavior of an organization, it is important to analyze its "ecology" (Pfeffer and Salancik, 1978: 1). It is perhaps an interest in understanding agencies that has led several scholars to examine their ecology, in particular their independence from external actors. Some might argue that it seems an obsession to assume that organizations have to be (in)dependent in relation to external actors. Nevertheless, given the interpretation that EAs were created to respond to the 
"credible commitment" problem, it has been, and continues to be, important to analyze whether decision-making in such bodies is related to the interests of certain external groups.

\section{The relevance of career analysis: Career analysis as a means to identify interpersonal ties}

This study examines the career trajectories of EA board members under the assumption that such trajectories could reflect previous connections with the political sphere or stakeholders. This study does not assume that actors are only driven by their professional background, nor that policy decisions within agencies are only driven by the sum of their members' individual preferences and actions. It is also true that ties between board members and stakeholders/ politicians may be unrelated to career trajectories (for example, a board member may have strong connections to politicians/stakeholders derived from family connections, personal contacts, and even due to ideological similarities). Nevertheless, previous studies have highlighted the importance of examining the professional trajectories of policy agents. For example, in an earlier study on the relationship between businesses and bureaucrats at the national level, Schneider (1993: 332) argued that the career paths of elite bureaucrats affect their "preferences, degrees of autonomy, and relations with capitalists". More recently, in a study on cabinet ministers in parliamentary democracies, Alexiadou (2015) finds that ministerial background affects the scope of the implemented social welfare reforms. In addition, current legislative studies have demonstrated the importance of analyzing legislators' backgrounds as drivers of their beliefs or their behavior in office (e.g., Witko and Friedman 2008). At the same time, following a different line of research on central banks, Adolph (2013) shows that policy agents are driven by their own career trajectories, specifically, that their professional background shapes their beliefs and, thus, their policy preferences/decisions (such as central banking decisions on inflation). In particular, Adolph (2013) has responded to the widespread 
belief that central banks produce neutral solutions owing to their independence, arguing that policy agents are not neutral since they are driven by their own career trajectories.

Although there are some studies examining professional careers at the executive and legislative branches, there has been very little analysis on the professional careers of policy-makers working in regulatory agencies. Significant studies developed by Ennser-Jedenastik (2015, 2016) and Fernández-i-Marín et al. (2016) have concentrated on examining political ties of high-ranking posts in national regulatory agencies. However, there is a lack of empirical studies centered on the professional trajectories of policy-makers serving in EAs, specifically, regarding their ties not only to politicians but also to interest groups. Therefore, this study starts by analyzing the professional backgrounds of EA board members with the aim of identifying their career connections with the two sets of actors suggested by the literature on agency independence: politicians and stakeholders. Further research could be focused on determining whether the professional backgrounds of the policy-makers influence their policy decisions, however, this article must first investigate the presence/absence of the above-mentioned type of connections.

\section{The relevance of the appointing body}

Different political principals participate in the institutional design of EAs (i.e., the Council, the EP, the Commission, and the Member States), as well as in the selection of top-level agency officials (e.g., Curtin 2007; Dehousse 2008; Font 2015; Kelemen 2002; Thatcher 2002). Previous studies have shown that political principals have an interest to control and supervise EAs performance. For example, some articles have emphasized the greater influ- 
ence of the Commission (e.g., Egeberg and Trondal 2011); some others, the control exercised by the Member States (e.g. Busuioc 2013); and some others, the increased oversight mechanisms carried out by the European Parliament (e.g., Font 2015; Font and Pérez-Durán 2016; Lord 2011). What these studies confirm is the notion that delegation takes place if political principals are able to control the agencies, and that neither the Member States nor the European institutions (the Commission, the Council and the EP) are indifferent to what EAs do. This study focuses on the "appointment stage" of top-level EA officials, understood as "the primary source of executive and legislative influence over policy outcomes" (Calvert et al. 1989: 604-605). In particular, the argument of political control suggests that political principals will be more likely to appoint "reliable agents" or else, "likeminded" individuals. It is true that the "credible commitment problem" would suggest that some political principals could be inclined to stimulate the appointment of board members with a more technocratic profile - that is, individuals with public management expertise. However, the argument of political control highly suggests that it seems reasonable to expect that political principals could be inclined to appoint two types of reliable agents: individuals having ties to stakeholder allies, and/or candidates with political ties. This study seeks to examine the role of the appointing body with the aim of identifying whether agency officials elected by the Commission, the EP, the Council, the Member States, or multiple veto players are more likely to enjoy ties to politicians and stakeholders.

The Commission as the appointing body

Empirical studies that have examined the political perceptions of European Commission officials have largely emphasized their technocratic nature: firstly, because although the Com- 
mission contains political and therefore "ideological elements in its structures", as the commissioners "are generally political heavyweights with backgrounds as former ministers and parliamentarians" (Egeberg et al. 2014: 5), the majority of its officials are normally recruited by competitive procedures based on merit and professional qualifications (Hooghe and Kassim 2012, Radaelli 1999). Secondly, in a study on the beliefs and policy preferences of top Commission officials, Hooghe (1999: 353-359) shows that their beliefs are in line with technocratic principles, as the majority of them argued that the Commission "should concentrate on maintaining the internal market" and "on administering things efficiently". The work developed by Egeberg and Trondal (2011: 869) suggests that, since EAs "tend to be much closer to the Commission than to any other institution surrounding them", board members elected by the Commission tend to be members of the Directorate-Generals (DGs). Therefore, one might expect that these representatives will have extensive public management experience without any type of political or stakeholder tie. Accordingly, the following hypothesis is tested:

H1: EA board members appointed by the Commission are less likely to have career ties to stakeholders and politicians than those appointed by other political principals.

\section{The EP as the appointing body}

Recent studies on agencification have emphasized that the EP has increased its power to exercise control over agencies - for instance, through its role as a co-legislator and through other instruments for supervising agencies, such as hearings with directors (Busuioc 2013; Lord 2011) and parliamentary questions (Font and Perez-Duran 2016). The existing literature 
on congressional dominance has extensively described different legislative tools/mechanisms to control agency decisions. For example, Moe (1987) points out three mechanisms of control that Congress has at its disposal in order to induce bureaucratic compliance: budgets, threats of new legislation, and appointments. According to Weingast and Moran (1983: 769), the latter are "the most effective means of influence" because "if Congress controls who gets appointed to agencies, then it controls which experts gain influence and control of agency management". The importance of appointments lies in the notion that these can be used "to fill administrative leadership positions with candidates whose philosophical, political, and professional backgrounds" are conducive to control (Moe 1987: 489). On this basis, one would expect that MEPs would try to choose "reliable agents" (Lupia and McCubbins 1994), with the aim of "assuring that agencies are responsive to their interest" (McCubbins, Noll and Weingast, 1987: 244).

On the one hand, one would expect that MEPs use such appointment procedures to enfranchise individuals having ties to politicians. The rationale behind the designation of co-partisans is that this direct control mechanism allows MEPs to ensure that agents will have similar policy preferences.

H2: Board members appointed by the European Parliament are more likely to have ties to politicians than those selected by the Commission.

On the other hand, previous studies have extensively argued that the EP has demanded the involvement of stakeholders in the institutional design of EAs. For example, Kelemen (2002: 1997) has demonstrated that the EP has demanded an institutional design "that provides it or 
its interest group allies with opportunities for control", specifically, through the establishment of fire alarm oversight processes by stakeholders. On this basis, one could expect that, with the aim to trace the policy-decisions of the agencies, MEPs would also seek to appoint as reliable agents candidates who, despite being outside the "political sphere", are close to politicians with whom they share political preferences and beliefs. MEPs would make use of this type of indirect control mechanism with the following aims: to avoid taking blame for policy decisions that could be unpopular among important constituents (Thatcher and Stone Sweet, 2002); as a way to guarantee that their relevant and "reliable constituents are well served" by the agencies (Calvert et al, 1989: 589); or else, to avoid political costs derived from the appointment of individuals with political ties, which could potentially undermine the political independence of the agencies — and therefore, their credibility — (Ennser-Jedenastik, 2015).

H3: Board members appointed by the European Parliament are more likely to have ties to stakeholders than those appointed by the Commission.

The Member States and the Council as the appointing bodies

Some scholars have pointed at the prominent role of national governments in the decisions and actions carried out by EAs. For example, Busuioc (2012) argues that during the first round of creation of EAs, the Member States played an important role in shaping the design of their governance structures. This prominent role of Member States is particularly characteristic in those EAs (such as OSHA, CEDEFOP or EUROFOUND) ${ }^{2}$ where there is a greater number of representatives of Member States than that of appointees by the Commission or

\footnotetext{
2 Please see the acronyms and full names of European Union agencies in Annex 1
} 
the EP. In a similar vein, Kelemen and Tarrant (2011: 928) argue that when delegation occurs, Member States are more likely to "maintain as much national control as possible to constrain the discretion of EU regulators". Accordingly, one would expect that national governments will be more likely to appoint board members having political ties for reasons of patronage (Kopecky et al 2016): either to reward and maintain political friends; or else, as an "organizational resource" to exercise/increase their control over such agencies (Ennser-Jedenastik 2015: 826).

H4: Board members whose main appointing body are Member States are more likely to have ties to politicians than those appointed by the Commission.

As for the Council of the European Union, a similar relationship is to be expected since this body is also composed of government ministers from each Member State. Nevertheless, the study presents two hypotheses differentiating between the role of the Council and the Member States, since while the former is based on its intergovernmental nature with collective decision-making processes that respond to such collectivity, the latter participate as autonomous actors responding to their respective domestic interests (Marks et al. 1996).

H5: Board members whose main appointing body is the Council are more likely to have ties to politicians than those appointed by the Commission.

Multiple veto players as the appointing body 
In some agencies, the appointment of board members requires an agreement among multiple actors/veto players (Tsebelis, 1995). For example, in the case of the EFSA, the board members should be appointed by the Council in consultation with the European Parliament from a list drawn up by the Commission which includes a number of candidates substantially higher than the number of members to be appointed. In a previous study on agency independence, Hanretty and Koop (2013: 198) identified that the presence of more veto players makes it more difficult for politicians "to sanction or reward the regulator", as they have less discretion to appoint their favorite candidates. This finding is based on Moe's (1990) theoretical argument, according to which bureaucracies would be more independent — and we can expect both dimensions of independence, from politicians and stakeholders, to have a greater presence - when they have multiple veto players. Therefore one can expect the following hypothesis:

H6: Board members appointed by virtue of an agreement among multiple veto players will be less likely to have ties to stakeholders and politicians.

However, in their study on veto players in the EU decision-making, Tsebelis and Yataganas (2002) suggest that preferences of political institutions - the preferences of the appointing bodies - can coincide or overlap: for example, both the Council and the European Parliament can be dominated by a centre-right coalition. In those circumstances, it can be expected that the power of multiple veto players becomes less important. In fact, in a current empirical study, Ennser-Jedenastik (2016) finds that the veto player structure does not have any impact on the independence of national agencies. On this basis, the following counter-hypothesis is presented: 
H7: The presence of multiple veto players does not have any impact on the appointment of board members having ties to stakeholders and politicians.

\section{Other potential explanatory factors}

Formal political independence of the agencies

Previous studies on the institutional design of EAs suggest that political principals will put higher attention to some EAs, therefore, being more inclined to designate their "reliable agents" to serve in such agencies. In a recent large-scale analysis of about 700 top-level appointments in over 100 national regulatory agencies of West European countries, Ennser-Jedenastik (2016: 510) finds that higher levels of formal independence invite politicization, since politicians want to compensate their loss of formal control by resorting to informal means. This argument relies on the rationale that "politicians will try to compensate their loss of formal powers over regulatory matters by using informal channels of influence - such as the appointment of political allies" (Ennser-Jedenastik 2016: 510). Since previous studies have analyzed the relationship between formal political independence and the presence of ties to politicians in national regulatory agencies, the present article seeks to provide some evidence in the case of EAs. As evidenced by the discussion above, one might expect the following hypothesis:

H8: Board members who belong to agencies that enjoy greater formal independence from their political principals are more likely to have ties to politicians. 
Regulatory agencies and informative agencies

Some studies have emphasized that EAs can be classified into three categories according to their "primary tasks": informative agencies, operational/management agencies and (quasi) regulatory agencies (Busuioc 2013; Kelemen 2002). Most studies have focused their attention on regulatory agencies because their decisions rely on legally binding standards (e.g. Wonka and Rittberger 2010). However, other scholars (Majone 1997) have highlighted the importance of informative agencies as they play an important role in an indirect way of regulation — the so-called "regulation by information"- through the process of collecting and transmitting information to decision-makers within EU institutions. Since both types of agencies could play an important role in the decision-making process, it might be expected that political principals would be more inclined to designate their reliable agents to serve in such agencies.

H9: Board members who belong to agencies primarily in charge of regulatory or informative tasks are more likely to have ties to stakeholders and to politicians than those who belong to agencies entrusted with management/operational tasks.

\section{Data and operationalization}

The article examines high-ranking appointees of EAs. In particular, I limited my attention to management board members, as these formally represent the highest level of responsibility (Buess 2015; Font 2015). Management boards are responsible for making overall 
management and budget decisions, such as setting the annual plans or adopting the budget of the agency. The composition of the management boards varies across EAs, but in general, boards can include members elected by the EU Member States, the Commission, the Council, the EP, non-EU countries, other EAs and representatives of stakeholders (Busuioc 2012). For example, the management board of the ECHA is composed of one representative from each Member State, "a maximum of six representatives" designated by the Commission, three individuals from interested parties and two persons appointed by the EP. ${ }^{3}$

To test the above-mentioned theoretical expectations, I constructed an original dataset documenting the professional trajectory of former and current EA board members over the period between January 2010 and September 2016. In particular, I focused on examining board members appointed by the Council, the EP, and the Commission. I also included a simple random sample of representatives of Member States. The study covers 338 board members serving in the 33 existing EAs (further details can be found in Annex 2).

Following previous studies by Fernández-i-Marín et al. (2016) and Ennser-Jedenastik (2015), I collected publicly available data on the careers of the board members by analyzing their Curricula Vitae (CV). This information was obtained from the website of the EAs as well as from professional websites (e.g., www.linkedin.com). The names of representatives from previous years were obtained from the Annual Reports of the agencies. However, the annual reports of 10 EAs (CEPOL, EASO, EFCA, EMSA, ETF, EU-LISA, EUROPOL, FRA, GSA and OHIM/EUIPO) do not provide the names of their board members. Regarding the cases of EFCA, ETF, FRA and GSA, the information was obtained from websites of previous years;

\footnotetext{
3 See Art. 79 - Regulation (EC) No 1907/2006 of the European Parliament and of the Council of 18 December 2006 establishing a European Chemicals Agency.
} 
and in the case of EMSA the names were extracted from the minutes of its management board meetings. In the case of EIOPA, the names of those representing the Commission do not appear on the list of board members provided on its website. Therefore, I also obtained that information from the minutes of its management board meetings. Finally, I verified some names with Council "Decisions" published at the Official Journal of the European Union (in the case of ACER, CdT, CEDEFOP, ECHA, EFSA, EIGE, EMA, EUROFOUND, and EUOSHA). Given that the analysis is based on the reported background of the board members, it is important to emphasize that — intentionally or not — not all background information could be reported. For example, one would expect board members to be more reluctant to report their political affiliations and to declare themselves as active political party members. However, as mentioned, previous studies examining national regulatory agencies (e.g. Fernández-i-Marín et al. 2016; Ennser-Jedenastik 2015), cabinet ministries (e.g. Alexiadou 2015), and some other institutions, such as central banks (e.g. Adolph 2013) have demonstrated the importance of analyzing career trajectories on the basis of this method.

This study aims to examine two dependent variables. The first dependent variable is the presence of ties to politicians. I used a dichotomous variable with 1 indicating whether each board member has (or has had in the past) ties to politicians (1), and 0 no ties. ${ }^{4}$ Specifically, I used the criteria followed by Ennser-Jedenastik (2015: 833) to code the party affiliation of board members: “(a) having held public political or party offices (e.g. minister, member of parliament, party leader); (b) having stood as a party candidate in elections; (c) having worked as an aide to party politicians (e.g. in a cabinet ministeriél or as an aide to a

\footnotetext{
${ }^{4}$ It is worth noting that I cannot use a multinomial dependent variable because in some cases there is an overlap between political ties and stakeholder ties. In particular, there are 25 board members ( 7.4 percent) who have both stakeholder and political ties. Moreover, I can run two separate models since the level of correlation between both variables "stakeholder ties" and "political ties" is 0.08 .
} 
parliamentary party group)." For example, board members with political ties include individuals with experience as ministers in their respective national governments, members of national parliaments, or members of the EP, among others.

The second dependent variable examines the presence of stakeholder ties. I also used a dichotomous variable with 1 indicating ties to stakeholders, and 0 indicating no ties. To do this, I used the definition of stakeholders developed in Klüver (2013), understood as actors who have three main components: organizational structure, political interest and private status. From this definition, I identified whether each board member has (or has had in the past) ties to stakeholders in the policy area covered by the agency in question: (a) if the appointee is currently working/has worked with stakeholders (business associations/firms, trade unions, civil society organizations, international organizations); and (b) if the appointee is affiliated/ has been affiliated to interest groups. ${ }^{5}$ For example, in the case of ACER, most board members who have been codified as having stakeholder ties have experience working for business groups/private consultancies specialized in the provision of electricity and energy services; regarding BEREC, board members have been employed in the information technology or electronic communications sectors; in the case of CEDEFOP, board members have worked in private organizations that develop and sell licenses and/or computer software; concerning the CPVO, board members have experience in the management of natural resources; in the case of EFCA, board members have been employed by fish processing companies; in the case of ECHA, board members have served in medical associations and pharmaceutical firms; regar-

\footnotetext{
${ }^{5}$ Alternatively to this categorical distinction in the operationalization of ties to politicians/stakeholders, Adolph (2013) identifies the proportion of time that central bankers have worked in different institutional contexts (e.g. in the government or in the private sector). The logic behind this alternative approach to the identification of interpersonal ties rests on the assumption that interpersonal ties are not equal. For example, two individuals (A and B) could have a strong or a weak tie. However, the present article seeks to examine, beyond the assessment of the strength of ties, the mere presence/absence of ties between board members and politicians/stakeholders.
} 
ding EFSA, board members have worked for private organizations specialized in the fields of food safety, nutrition security and sustainable agriculture; and in the case of FRA, board members have experience in civil society organizations protecting the rights of children and women.

The independent variables were operationalized as follows. To test the hypothesis on the type of appointing body, I identified the main appointing body of each board member. Specifically, I created a categorical variable indicating whether board members were elected by the Commission (=1), the EP (=2), the Council (=3), the Member States (=4), or else, by multiple veto players $(=5){ }^{6}$ To test the hypothesis on agency tasks, I followed Busuioc's (2013) classification of EA primary tasks. Specifically, I used a categorical variable indicating whether agencies perform regulatory tasks $(=1)$-ACER, BEREC, CPVO, EASA, EBA, ECHA, EFSA, EIOPA, EMA, EMSA, ERA, ESMA, OHIM, and SRB—; informative tasks $(=2)$ - CEDEFOP, EEA, EIGE, EMCDDA, ENISA, EUSC, EUROFOUND, EU-OSHA, and FRA—; or a different type of task, specifically, management tasks and/or operational tasks $(=3)$ - e.g. FRONTEX and ETF-. For the hypothesis regarding the formal independence of agencies, I used the index developed by Wonka and Rittberger (2010). ${ }^{7}$

Since current studies have found that agency designers have provided some EAs with formal representation of stakeholders in their most important decision-making bodies (e.g., Christen-

\footnotetext{
${ }^{6}$ It is worth noting that the management boards of EBA, ESMA and EIOPA include six board members elected by and from the voting members of their respective Board of Regulators (which are composed by the head of the national public authority competent for the supervision of financial market participants in each Member State with the right to vote, as well as by one representative of the Commission, one representative of each of the other two European Supervisory Authorities and one representative of the ESRB - none of them has the right to vote). Since such members represent national authorities, they have been codified as representatives of Member States.

7 The study developed by Wonka and Rittberger (2010) assesses the formal political independence of 27 EAs, therefore, I obtained the index value of the remaining agencies.
} 
sen and Nielsen 2010), I also included a control variable expecting that the appointing bodies would be less likely to designate as board members individuals who have links with stakeholders in agencies that already have formal representation of such groups. To do this, I included a dichotomous variable to indicate whether the statutes of EAs (in particular their establishing/founding regulations) establish a formal representation of stakeholders in the management boards (the cases of CEDEFOP, EASA, ECHA, EFSA, EMA, EMSA, ERA, EUROFOUND and EU-OSHA), in their "Advisory/Expert Forums" (the cases of ECDC and EIGE), or whether agencies have a permanent "Stakeholder Group" (EBA, ESMA, ENISA and EIOPA).

Finally, I also collected information on other characteristics of board members such as gender; nationality; field(s) of studies in their educational background; experience in the public sector (at the national and European Union levels), in the private sector, and in the academia; as well as type of stakeholder (i.e., if the board member has been linked to firms/private consultancies, trade unions, civil society organizations or international organizations).

\section{Analysis and Results}

The analysis of the career trajectories of the board members included in our dataset yields the following descriptive information. Firstly, there is a majority of men in EA management boards, since 69 percent of the individuals analyzed are men while only 31 percent are women. Regarding the nationality of board members, some Member States seem more predominant than others: 10.6 percent of them are from Germany, 7.4 percent are from Spain, 8.8 percent are from France, and 7.4 percent are from Italy - the information available does 
not allow me to identify the nationality of 7.4 percent of the board members included in the dataset- (see Figure 1). Regarding their educational level, the information reveals that "bachelor's degree" is the highest educational qualification for 23 percent of the examined board members, "master's degree" is the highest completed level of education for 37 percent of them, and 31 percent of the members have obtained a $\mathrm{PhD}$ degree - the information available does not allow me to identify the educational attainment of 9 percent of the board members included in the dataset-(see Figure 2). The information also shows that three disciplines predominate in their academic background: law, "hard sciences" (mathematics, physics, engineering) and "life sciences" (medicine, biology, chemistry, pharmaceutics). For example, 23 percent of the board members have a bachelor's degree in law, 14 percent have studied a degree related to hard sciences and 13 percent have a life sciences background. In addition, 9 percent have completed undergraduate studies in economics and 5 percent opted for a bachelor's degree in political science/public administration - this variable could not be measured in 22 percent of the individuals included in the dataset- (see Figure 3). Among those board members having a $\mathrm{PhD}, 27$ percent have a $\mathrm{PhD}$ in law, 14 percent in hard sciences, 38 percent in life sciences, 16 percent in economics, 3 percent in political science/public administration, and 3 percent in business administration. Finally, 68 percent of the members have professional experience at the national level, 54 percent at the EU level, 28 percent at the private sector, 5 percent at NGOs, 10 percent at international organizations, and 19 percent have worked full-time at a university/research institution at some stage of their career.

[Figures 1-3 Country of origin, Educational level, and Field of study (Bachelor's Degree)] 
Notes: Number of observations included: 351 board members / NS= no data available / Country of origin: $\mathrm{DE}=$ Germany, $\mathrm{FR}=$ France, $\mathrm{IT}=\mathrm{Italy}, \mathrm{ES}=$ Spain, $\mathrm{UK}=$ United Kingdom, $\mathrm{DK}=$ Denmark, $\mathrm{PT}=\mathrm{Portugal}$, $\mathrm{PL}=$ Poland, $\mathrm{GR}=$ Greece, $\mathrm{BE}=$ Belgium, $\mathrm{SE}=$ Sweden, $\mathrm{NL}=$ Netherlands, $\mathrm{AU}=$ Austria, $\mathrm{RU}=\mathrm{Romania}$, $\mathrm{CY}=$ Cyprus, $\mathrm{HU}=$ Hungary, $\mathrm{FI}=$ Finland, $\mathrm{CZ}=$ Czech Republic, $\mathrm{ML}=$ Malta, $\mathrm{SK}=$ Slovakia, $\mathrm{IE}=\mathrm{Ireland}$, $\mathrm{SI}=\mathrm{Slove}-$ nia, $\mathrm{HR}=$ Croatia, $\mathrm{EE}=$ Estonia, $\mathrm{BG}=$ Bulgaria, $\mathrm{LX}=$ Luxembourg, $\mathrm{LT}=$ Lithuania, $\mathrm{LV}=$ Latvia / Field of Study: Hard Sci=Hard Sciences (i.e. Mathematics, Physics, Engineering), Life Sci= Life Sciences (i.e. Biology, Medicine, Chemistry, Pharmaceutics), Econ= Economics, Other= Other (i.e. Linguistics, Humanities), Pol Sci= Political Science, Public Administration, BA= Business Administration, IR= International Relations.

The results reveal that 15.4 percent of the board members (52 board members) have career political ties — these are particularly present in some agencies, such as ACER, ECHA, EMA EMCDDA and ETF-; and 39.1 percent (132 members) have career stakeholder ties — this practice is more common in agencies such as ACER, EBA, EFSA, EIOPA, ESMA, GSA, SRB and EEA. Among board members having ties to stakeholders, 62.3 percent have ties to business groups/private consultancies, 6.2 percent to NGOs, 3.9 percent to trade unions, and 19.2 percent to international organizations. The remaining members have ties to multiple types of stakeholders (e.g., professional experience in international organizations, NGOs and/ or firms).

As the two dependent variables are binary variables and the dataset follows a hierarchical structure -338 board members (level 1) nested in 33 EAs (level 2)—, I estimated multilevel logistic regression models. The results are shown in Table 1.

[Table 1 Explaining political ties and stakeholder ties of EA management board members]

Note: Standard errors in parentheses. Significant at $* \mathrm{p} \leq .10 ; * * \mathrm{p} \leq .05 ; * * * \mathrm{p} \leq .01$ 
As expected in $\mathrm{H} 2$, the results suggest that the European Parliament is more likely - than the Commission - to appoint individuals having political ties. For example, Figure 4 shows that, when the EP is the appointing body, the predicted probability of finding a board member with political ties is 0.63 . It is important to mention that the EP has the power to designate board members in 10 agencies. Still, what the evidence provided by the analysis suggests is that the EP may seek to keep de facto political control mechanisms over such agencies through the nomination of political "allies". The results do not provide evidence that the EP prefers the appointment of candidates with a professional profile primarily linked to interest groups.

In H6 I expected that EA management board members appointed by an agreement among multiple veto players would be more independent from both politicians and stakeholders. However, the results suggest that such actors are less likely to designate individuals having career ties to politicians (see Figure 4). Although this result is limited to EFSA and SRB the two agencies in which multiple veto players have power of appointment-, it supports the expectation of less designations of candidates connected with politicians.

[Figure 4 Predicted probabilities by type of appointing body]

[Figure 5 Predicted probabilities by agency task]

Note: Predicted probabilities based on the multilevel logistic regression model regarding political ties.

As noted, hypothesis $\mathrm{H} 9$ expected that board members who belong to agencies primarily in charge of regulatory tasks would be more likely to have ties to stakeholders and to politicians 
than those who participate in agencies undertaking management/operational tasks. However, the findings only give credence to the interpretation that those agencies that carry out binding decisions draw more attention from their political principals, who therefore are more inclined to appoint their reliable agents having political ties as board members -Figure 5 shows a predicted probability of 0.19 -

In addition, contrary to the theoretical expectations, formal political independence does not have a statistically significant effect on the presence of de facto career connections with political or stakeholder agents. However, it is worth noting that formal independence and agency task have a correlation coefficient of 0.39 , which could make it difficult to differentiate the effect of formal independence. For this reason, I also run the same statistical models removing the agency task variable, but the effect of formal independence is not altered.

Finally, since I am not including all the individuals appointed by the Member States, I also applied sampling weights (pweights) at level 1 (see Annex 2). I applied this process of weighting with the aim to balance the sample and, specifically, to correct the lack of representation of Member State appointees. The estimates have been performed using the GLLAMM (Generalized Linear Latent and Mixed Models) command in Stata (Rabe-Hesketh and Skrondal, 2012). As can be seen in Annex 3, the results obtained regarding the presence of political ties are largely in line with previous results from the unweighted model. However, the results differ when I run the analysis for the presence of stakeholder ties: while no variable reaches a level of significance of $\mathrm{p} \leq .10$ in the unweighted model, four covariates appear to have a significant effect in the weighted model. For example, these results suggest that both the Council and multiple veto players are more likely — than the Commission — to se- 
lect board members having ties to stakeholders (see Annex 3). However, the results cannot be confirmed since the sampling error is large due to the small sample size of Member State representatives. Therefore, further analysis will benefit from the inclusion of a larger sample size of Member State appointees.

\section{Conclusions}

The original aim of this study was to contribute to the scholarship on agencification by focusing on the relationship between EAs and politicians, and between EAs and stakeholders. Before taking for granted that these agencies are able to enhance the legitimacy and the credibility of the policy-making process and, given that EAs are not subject to majoritarian democratic procedures, it is important to know who their top-officials are. For this purpose, this research has examined the professional trajectory of EA board members, identifying their career links with politicians and specific stakeholders.

The present article has brought evidence on the professional trajectories of EA management board members on the basis of an original dataset. The analysis showed that 15.4 percent of the board members have political ties, and 39.1 percent have stakeholder ties - mainly to business groups/private consultancies working in the policy area covered by the agency in question. I have highlighted that 62 percent of the members with stakeholder ties are linked to business groups, whereas only 6 percent have career ties to civil society organizations, and 4 percent to trade unions. The question regarding the professional background of the remaining management board members examined still remains to be answered: our dataset showed 
that most of these individuals have worked in the public sector — both/either at the national and/or the EU level—, whereas a small percentage of them have served in universities and/or research centres.

This study has shown that the type of appointing body affects the selection of individuals with certain professional backgrounds. Thus, the European Parliament is more likely to appoint individuals linked to political allies —or else, individuals that have themselves been political players throughout their career-. For their part, agency officials elected by multiple veto players are less likely to have career ties to political players. Finally, the findings also suggested that agency characteristics matter. In particular, the results showed that agencies undertaking regulatory tasks — those agencies that carry out binding decisions - are more inclined to have lower levels of de facto independence from politicians.

The findings derived from this article point to three lines of future research. Firstly, the analysis of the professional background of all the Member State representatives, particularly with the aim of examining whether board members appointed by different types/groups of Member States are more likely to have ties to politicians and interest groups. Secondly, the study of professional trajectories as an explanatory variable of the policy decisions carried out by board members. Thirdly, a more extensive investigation would allow me to delve into the relationship between EAs and interest groups by examining the evolution of the professional careers of the board members after leaving the EAs. 


\section{References}

Adolph, C. (2013). Bankers, Bureaucrats, and Central Bank Politics: The Myth of Neutrality. Cambridge Series in Comparative Politics. Cambridge and New York: Cambridge University Press.

Alexiadou, D. (2015). Ideologues, partisans, and loyalists: Ideologues, partisans, and loyalist: Cabinet Ministers and Social Welfare Reform in Parliamentary Democracies. Comparative Political Studies, 48, 1051-1086.

Borrás, S., Koutalakis, C., and Wendler, F. (2007). European agencies and input legitimacy: EFSA, EMeA and EPO in the post-delegation phase. Journal of European Integration, 29, 583-600.

Buess, M. (2015). European Union agencies and their management boards: an assessment of accountability and demoi-cratic legitimacy. Journal of European Public Policy, 22, 94111.

Busuioc, M. (2012). European agencies and their boards: promises and pitfalls of accountability beyond design. Journal of European Public Policies, 19, 719-736.

Busuioc, M. (2013). European Agencies: Law and Practices of Accountability. Oxford: Oxford University Press.

Calvert, R.L., McCubbins, M.D. and Weingast, B.R. (1989). A theory of political control and agency discretion. American Journal of Political Science, 33, 588-611.

Christensen, J.G., and Nielsen, V.L. (2010). Administrative capacity, structural choice and the creation of EU agencies. Journal of European Public Policy, 17, 176-204.

Curtin, D. (2007). Holding (Quasi-)Autonomous EU Administrative Actors to Public Account. European Law Journal, 13, 523-541.

Dehousse, R. (2008). Delegation of powers in the European union: The need for a multi-principals model. West European Politics, 31, 789-805.

Egeberg, M., and Trondal, J. (2011). EU-level agencies: new executive centre formation or vehicles for national control? Journal of European Public Policy, 18, 868-87.

Egeberg, M., Gornitzka, A. and Trondal, J. (2014) A Not So Technocratic Executive? Everyday Interaction between the European Parliament and the Commission. West European Politics, 37, 1-18.

Ennser-Jedenastik, L. (2015). Credibility Versus Control: Agency Independence and Partisan Influence in the Regulatory State. Comparative Political Studies, 48, 823-853.

Ennser-Jedenastik, L. (2016). The Politicization of Regulatory Agencies: Between Partisan Influence and Formal Independence. Journal of Public Administration Research and Theory, 26, 507-518.

Fernández-i-Marín X., Jordana J., and Bianculli, A.C. (2016). Are regulatory agencies independent in practice? Evidence from board members in Spain. Regulation \& Governance. 10, 230-247. 
Flinders, M. and Buller, J. (2006). Depoliticisation: principles, tactics and tools. British Politics, 1, 293-318.

Follesdal, A. and Hix, S. (2006). Why There is a Democratic Deficit in the EU: A. Response to Majone and Moravcsik. Journal of Common Market Studies, 44, 533-562.

Font, N. (2015). Policy properties and political influence in post-delegation: the case of EU agencies. International Review of Administrative Sciences, 84, 773-792.

Font, N. and Pérez Durán, I. (2016). The European Parliament oversight of EU agencies through written questions. Journal of European Public Policy, 23, 1349-1366.

Gilardi, F. (2002). Policy credibility and delegation to independent regulatory agencies: a comparative empirical analysis. Journal of European Public Policy, 9, 873-93.

Gilardi, F. and Maggetti, M. (2011). The Independence of Regulatory Authorities. In D. LeviFaur (Ed.), Handbook on the Politics of Regulation, Cheltenham (pp. 201-214): Edward Elgar.

Hanretty, C. and Koop, C. (2012). Measuring the formal independence of regulatory agencies. Journal of European Public Policy, 19, 198-216.

Hanretty, C. and Koop, C. (2013). Shall the law set them free? The formal and actual independence of regulatory agencies. Regulation \& Governance, 7, 195-214.

Hooghe, L. and Kassim, H. (2012). The Commission's Services. In J. Peterson and M. Shackleton (Eds.), The Institutions of the European Union. Oxford (pp. 174-197): Oxford University Press.

Hooghe, L. (1999). Images of Europe: Orientations to European Integration among Senior Officials of the Commission. British Journal of Political Science, 29, 345 - 367.

Jordana, J., Levi-Faur, D. and Fernández-i-Marín, X. (2011). The global diffusion of regulatory agencies: Channels of transfer and stages of diffusion. Comparative Political Studies, 44, 1343- 1369.

Kelemen, D.R. (2002). The Politics of 'Eurocratic' Structure and the New European Agencies. West European Politics, 25, 93-118.

Kelemen, D.R. and Tarrant A. D. (2011). The Political Foundations of the Eurocracy, West European Politics, 34, 922-947.

Kelemen D.R. (2012) European Union agencies. In E. Jones, A. Menon and S. Weatherill (Eds.) The Oxford Handbook of European Union. Oxford (pp. 392-403): Oxford University Press.

Klüver H (2013) Lobbying as a Collective Enterprise: Winners and Losers of Policy Formulation in the European Union. Journal of European Public Policy 20(1), 59-76.

Kopecky, P., Meyer-Sahling, J.H., Panizza, F., Scherlis, G., Schuster, C. and Spirova, M.S. (2016). Party patronage in contemporary democracies: Results from an expert survey in 22 countries from ve regions. European Journal of Political Research, 55(2), 416-431.

Levi-Faur, D., and Jordana J. (2005). The global diffusion of regulatory capitalism. Annals of the American Academy of Political and Social Science, 598, 12-32. 
Lord, C. (2011). The European Parliament and the legitimation of agencification. Journal of European Public Policy, 18, 909-925.

Lupia, A. and McCubbins, M.D. (1994). Learning from oversight: Fire alarms and police patrols reconstructed. Journal of Law, Economics, \& Organization, 10, 96-125.

Majone, G. (1996). Regulating Europe. London: Routledge.

Majone, G. (1997). The new European agencies: regulation by information. Journal of European Public Policy, 42, 262-275.

Marks, G., Hooghe, L. and Blank, K. (1996). European integration from the 1980s: State-centric v. multilevel governance, Journal of Common Market Studies, 34, 341-378.

McCubbins, M.D., Noll, R.G. and Weingast, B.R. (1987) Administrative Procedures as Instruments of Political Control. Journal of Law, Economics, \& Organization 3, 243-277.

Moe, T. (1987). An assessment of the positive theory of "Congressional Dominance". Legislative Studies Quarterly, 12, 475-520.

Moe, T. (1990). The neglected side of the story. Journal of Law, Economics \& Organization, 6, 213-253.

Pfeffer, J. and Salancik, G. (1978). The External Control of Organizations. A Resource Dependence Perspective. Harper \& Row, New York.

Rabe-Hesketh, S., \& Skrondal, A. (2012). Multilevel and Longitudinal Modeling Using Stata (Third Edition). College Station, TX: Stata Press. Volume II: Categorical Responses, Counts, and Survival.

Radaelli, C.M. (1999). Technocracy in the European Union. London: Longman.

Rittberger, B. and Wonka, A. (2011). Introduction: agency governance in the European Union. Journal of European Public Policy, 18, 780-789.

Schneider, B.R. (1993). The Career Connection: A Comparative Analysis of Bureaucratic Preferences and Insulation. Comparative Politics, 25, 331-350.

Stigler, G.J. (1971). The theory of economic regulation. The Bell Journal of Economics and Management Science, 2, 3-21.

Thatcher, M. (2002). Delegation to independent regulatory agencies: pressures, functions and contextual mediation. West European Politics, 25, 125-147.

Thatcher, M. and Stone Sweet, A. (2002) Theory and Practice of Delegation to Non-Majoritarian Institutions, West European Politics, 25, 1-22.

Tsebelis, G. (1995). Decision making in political systems: Veto players in presidentialism, parliamentarism, multicameralism and multipartyism. British Journal of Political Science, 25, 289-325.

Tsebelis, G., and Yataganas, X. (2002). Veto Players and Decision-making in the EU after Nice: Policy Stability and Bureaucratic/Judicial Discretion, Journal of Common Market Studies, 40, 283-307.

Vibert, F. (2007). The rise of the unelected: Democracy and the new separation of powers. Cambridge: Cambridge University Press. 
Weingast, B. and Moran, M. (1983). Bureaucratic discretion and political control. Journal of Political Economy, 91, 765-800.

Witko, Christopher, and Sally Friedman (2008). Business Backgrounds and Congressional Behavior. Congress \& the Presidency, 35, 71-86.

Wonka, A. and Rittberger, B. (2010). Credibility, Complexity and Uncertainty: Explaining the Institutional Independence of 29 EU Agencies. West European Politics, 33, 730-752.

Wood, M. (2015). Politicisation, Depoliticisation and Anti-Politics: Towards a Multilevel Research Agenda. Political Studies Review. (OnlineFirst) DOI: 10.1111/1478-9302.12074. 